\title{
ANALISIS KINERJA PENDAMPING LOKAL DESA DI DESA KARANGJAYA KECAMATAN NAMLEA KABUPATEN BURU PROVINSI MALUKU
}

\author{
Oleh \\ Muhammad Ikrom Seknun', \\ Khasan Effendy ${ }^{2}$, M. Irwan Tahir ${ }^{3}$ \\ 1) Pemerintah Daerah Provinsi Maluku \\ Program Magister Terapan Studi Pemerintahan Daerah Institut Pemerintahan Dalam Negeri \\ ikramseknun93@gmail.com \\ ${ }^{2,3)}$ Institut Pemerintahan Dalam Negeri
}

\begin{abstract}
PERFORMANCE ANALYSIS OF LOCAL VILLAGE FACILITATORS IN KARANGJAYA VILLAGE NAMLEA SUBDISTRICT, BURU DISTRICT, MALUKU PROVINCE
\end{abstract}

$T$

This study aims to determine and analyze the performance of Village Local Assistants in Karangjaya Village, Namlea District, Buru District, Maluku Province, then to identify and analyze the factors that affect the performance of Village Local Assistants in carrying out assistance tasks in Karangjaya Village, Namlea District, Buru Regency, Maluku Province. The research design used in this research is descriptive research design with a qualitative approach, using primary data and secondary data obtained through the process of interviews, observation, and documentation from data sources in the form of person, place and paper.

The results of this study indicate that the performance of village local assistants in Karangjaya village, Namlea subdistrict, hunting district has not been maximized according to its main duties and functions as regulated in the PDTT Permendes Number 18 of 2019 concerning General Guidelines for Village Community Assistance. This is because according to the theory according to T.R. Mitchell, it is found that the quality of work of village local assistants is not optimal, timeliness is not optimal, lack of initiatives initiated by village local assistants, inadequate ability es and communication is not optimal. The less than optimal performance of local village assistants is influenced by several factors such as a lack of training and other capacity building activities, inadequate work support facilities, and a work environment that is not fully supportive.

Keywords: performance, village community assistance, village local assistants

\footnotetext{
ABSTRAK

$\mathrm{P}$ enelitian ini bertujuan untuk mengetahui dan menganalisis kinerja Pendamping Lokal Desa di Desa Karangjaya Kecamatan Namlea Kabupaten Buru Provinsi Maluku, kemudian untuk mengetahui dan menganalisis faktor-faktor yang memengaruhi kinerja Pendamping Lokal Desa dalam melaksanakan tugas Pendampingan di Desa Karangjaya Kecamatan Namlea Kabupaten Buru Provinsi Maluku.Desain penelitian yang digunakan dalam penelitian ini adalah desain penelitian deskriptif dengan pendekatan kualitatif, dengan menggunakan data primer dan sekunder yang diperoleh melalui proses wawancara, observasi, dan dokumentasi dari sumber data berupa person, place, dan paper.
} 
Hasil penelitian ini menunjukkan bahwa kinerja Pendamping Lokal Desa di Desa Karangjaya kecamatan Namlea Kabupaten Buru belum maksimal sesuai dengan tugas pokok dan fungsinya sebagaimana diatur dalam Permendes PDTT No. 18 Tahun 2019 tentang pedoman Umum Pendampingan Masyarakat desa. hal ini dikarenakan menurut teori menurut T.R. Mitchell, ditemukan kualitas kerja Pendamping Lokal Desa yang belum maksimal, ketepatan waktu yang belum maksimal, kurangnya inisiatif yang digagas oleh pendamping lokal desa, kemampuan yang belum memadai serta komunikasi yang dilakukan belum maksimal. Kinerja Pendamping Lokal Desa yang belum maksimal ini dipengaruhi oleh beberapa faktor seperti kurangnya pelatihan dan kegiatan peningkatan kapasitas lainnya, sarana pendukung kerja yang belum memadai, serta lingkungan kerja yang belum sepenuhnya mendukung.

Kata kunci: kinerja, pendampingan masyarakat desa, pendamping lokal desa

\section{PENDAHULUAN}

$\mathrm{D}$ esa adalah kesatuan masyarakat hukum yang memiliki batas wilayah yang berwenang untuk mengatur dan mengurus urusan pemerintahan, kepentingan masyarakat setempat berdasarkan prakarsa masyarakat, hak asal usul, dan/atau hak tradisional yang diakui dan dihormati dalam sistem pemerintahan Negara Kesatuan Republik Indonesia (Pasal 1 ayat (1) UndangUndang No. 6 Tahun 2014 tentang Desa). Diberlakukannya Undang-Undang No. 6 Tahun 2014 ini, menegaskan komitmen politik dan konstitusional bahwa negara melindungi dan memberdayakan desa agar menjadi kuat, maju, mandiri, dan demokratis sehingga dapat menciptakan landasan yang kokoh dalam melaksanakan pemerintahan dan pembangunan.

Pembangunan perdesaan merupakan bagian integral dan pembangunan nasional merupakan usaha peningkatan kualitas sumber daya manusia perdesaan dan masyarakat secara keseluruhan yang dilakukan secara berkelanjutan berdasarkan pada potensi dan kemampuan perdesaan. Dengan kecenderungan pembangunan yang terpusat di daerah perkotaan mengakibatkan pembangunan di desa menjadi tertinggal. Hal ini terlihat dari data yang dirilis oleh Kementerian Desa, yang dirilis dimuat dalam diagram berikut.

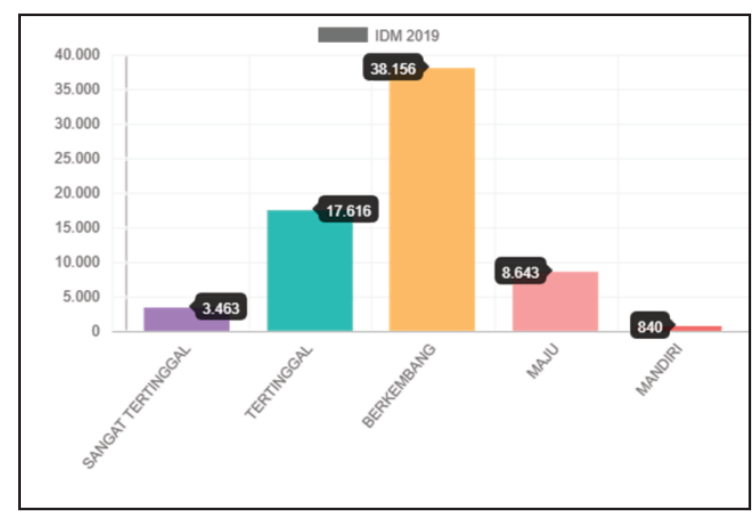

Gambar 1.

Indeks Desa Membangun 2019

Sumber: idm.kemendesa.go.id

Berdasarkan data tersebut, maka dapat dikatakan bahwa masih terdapat 21.079 Desa atau $28 \%$ dari 74.954 desa di Indonesia yang tergolong Desa sangat tertinggal dan tertinggal kemudian desa dengan kategori maju sekitar 8.643 desa atau sekitar 11,5\% dan desa dengan kategori mandiri hanya sekitar 840 desa atau 1,1\% dari jumlah desa di Indonesia. Untuk menjawab berbagai tuntutan-tuntutan dan permasalahan-permasalahan yang ada di tingkat Desa serta merealisasikan nawacita Presiden tersebut maka pemerintah dalam hal ini melalui Kementerian Desa, Pembangunan Daerah Tertinggal, dan Transmigrasi Republik Indonesia sejak 2015 membuat kebijakan Pendampingan Desa yang berdasarkan pada Undang-Undang Desa No. 6 Tahun 2014 tentang Desa dan Peraturan Pemerintah No. 47 Tahun 2015 tentang Peraturan Pelaksanaan 
Undang-Undang No. 6 Tahun 2014 yang diatur dalam Peraturan Menteri Desa.

Pendampingan desa bukan hanya sekadar menjalankan amanat UndangUndang Desa, tetapi juga modal penting untuk mengawal perubahan desa untuk mewujudkan desa yang mandiri. Adanya Pendampingan desa diharapkan mampu mendongkrak perubahan dalam masyarakat desa serta bergerak cepat untuk menyusun strategi dalam menuntaskan kemiskinan dan mengurangi kesenjangan sosial, tentunya sasarannya adalah pembangunan fisik, sarana prasarana desa, pemberdayaan masyarakat dengan tujuan membuka seluasluasnya terhadap pembangunan desa.

\section{Pemerintahan dan Manajemen Pe- merintahan}

Menurut Ndraha (2015), pemerintah adalah organ yang berwenang memproses pelayanan publik dan berkewajiban memproses pelayanan civil bagi setiap orang melalui hubungan pemerintah, sehingga setiap anggota masyarakat yang bersangkutan menerimanya pada saat diperlukan sesuai dengan tuntutan (harapan) yang diperintah. Pranadjaja (2003) dalam bukunya yang berjudul Hubungan Antara Instansi Pemerintah, gagasan Pemerintah menjelaskan bahwa istilah ini berasal dari Pemerintah kata perintah, yang berarti katakata yang bermaksud disuruh melakukan sesuatu, sesuatu harus dilakukan. Pemerintah adalah orang, badan atau aparat dihapus atau memberi perintah.

Menurut Nawawi (dalam Hamid, 2018: 36), secara normatif dari sisi yang lebih teknis, tujuan utama dibentuknya pemerintahan adalah untuk menjaga suatu sistem ketertiban di mana masyarakat bisa menjalani kehidupannya secara wajar.

Konsep dasar dari manajemen pemerintahan tidak lain adalah manajemen itu sendiri. Manajemen pada intinya menurut Ndraha adalah bagaimana menciptakan effectiveness usaha (doing right things) secara efficient (doing things right) dan produktif, melalui fungsi dan skill tertentu, dalam rangka mencapai tujuan organisasional yang telah ditetapkan (Ndraha, 2011: 159).

\section{Kinerja dan Indikator Kinerja}

Istilah kinerja berasal dari kata performance (pelaksanaan dari sebuah tanggung jawab), yaitu suatu pekerjaan lebih ditekankan pada proses, di mana selama pelaksanaan pekerjaan tersebut dilakukan penyempurnaan sehingga pencapaian hasil pekerjaan atau kinerja dapat dioptimalkan. Penilaian dari suatu pekerjaan menentukan kedudukan rasio pekerjaan-pekerjaan dalam suatu organisasi (Haynes dalam Sinambela, 2012: 5).

Substansi mengenai indikator pengukuran kinerja ini terdiri atas aspekaspek yang berpengaruh terhadap kualitas pelaksanaan tugas dan yang dapat diukur (T.R. Mitchell dalam Sedarmayanti, 2007) meliputi:

1. Kualitas kerja (quality of work)

2. Ketepatan waktu (pomptness)

3. Inisiatif (initiative)

4. Kemampuan (capability)

5. Komunikasi (communication)

\section{Tujuan dan Fungsi Pendampingan}

Pendampingan bisa dihubungkan dengan sikap dan tindakan yang dilakukan oleh orang yang tidak berprofesi bantuan psikologis secara penuh waktu, namun menginginkan layanannya lebih manusiawi (Wiryasaputra, 2006: 57-59).

Menurut Wiryasaputra (2006: 79) Tugas utama seorang pendamping adalah membantu orang yang didampingi untuk mengalami pengalamannya secara penuh dan utuh. Dengan demikian pendamping membantu orang yang didampingi merayakan suka dan duka kehidupan secara penuh dan utuh. 
Menurut Wiryasaputra (2006: 86), dalam menanggapi keprihatinan itu pada dasarnya pendamping sebagai fasilitator perubahan dalam proses pendampingan yang dapat memfungsikan diri dalam berbagai cara:

1. Menyembuhkan

2. Menopang

3. Membimbing

4. Memperbaiki hubungan

5. Memberdayakan/memperkuat

\section{Pendampingan Masyarakat Desa}

Pada Peraturan Pemerintah No. 47 Tahun 2015 tentang Perubahan Peraturan Pemerintah No. 43 Tahun 2014 tentang Peraturan Pelaksanaan Undang-Undang No. 6 Tahun 2014 tentang Desa, tenaga pendamping harus memiliki kompetensi dan kualifikasi pendampingan di bidang penyelenggaraan pemerintahan, ekonomi, sosial, budaya, dan/atau teknik.

\section{Pendamping Lokal Desa}

Pendamping Lokal Desa atau PLD adalah merupakan sebuah jabatan sebagai tenaga Profesional di bawah Kementerian Desa, Pembangunan Daerah Tertinggal dan Transmigrasi yang dibentuk berdasarkan Undang-Undang No. 6 dan kemudian diatur dalam Peraturan Menteri Desa, Pembangunan Daerah Tertinggal dan Transmigrasi No. 18 Tahun 2019 tentang Pedoman Umum Pendampingan Masyarakat Desa guna membantu Menteri, pemerintah daerah provinsi dan pemerintah daerah kabupaten/kota dalam melakukan Pendampingan Masyarakat Desa.

Pendamping Lokal Desa adalah merupakan Salah satu tenaga Profesional yang memiliki fungsi:
a. Fasilitasi;
b. Edukasi;
c. Mediasi; dan
d. Advokasi.

\section{Pengertian Desa, Pemerintahan Desa, dan Pemerintah Desa}

Menurut Kamus Besar Bahasa Indonesia, desa adalah satu kesatuan wilayah yang dihuni oleh sejumlah keluarga yang mempunyai sistem pemerintahan sendiri (dikepalai oleh seorang Kepala Desa) atau desa merupakan kelompok rumah luar kota yang merupakan kesatuan. Sementara itu, Wasistiono dan Tahir (2006: 7) kata desa sendiri berasal dari bahasa India, yakni swadesi yang berarti tempat asal, tempat tinggal, negeri asal, atau tanah leluhur yang merujuk pada satu kesatuan hidup, dengan satu kesatuan norma, serta memiliki batas yang jelas.

Di dalam Undang-Undang No. 6 Tahun 2014 tentang Desa, Pemerintahan Desa adalah penyelenggaraan urusan pemerintahan dan kepentingan masyarakat setempat dalam sistem pemerintahan Negara Kesatuan Republik Indonesia.. Pemerintah Desa adalah Kepala Desa atau yang disebut dengan nama lain dan yang dibantu oleh perangkat desa atau yang disebut dengan nama lain. Di dalam Pasal 25 disebutkan bahwa Pemerintah desa adalah Kepala Desa atau yang disebut dengan nama lain dan yang dibantu oleh perangkat desa atau yang disebut dengan nama lain. Pemerintah desa yang dipimpin oleh Kepala Desa. Kepala Desa dibantu oleh sekretaris desa dan perangkat desa. Perangkat desa terdiri dari atas kepalakepala urusan, pelaksana urusan, dan kepala dusun. Kepala-kepala urusan membantu sekretaris desa menyediakan data dan informasi dan memberi pelayanan.

\section{METODE PENELITIAN}

Tipe penelitian yang digunakan adalah penelitian deskriptif kualitatif. Creswell mengemukakan berikut ini.

"Proses penelitian kualitatif ini melibatkan upaya-upaya penting, seperti mengajukan pertanyaan-pertanyaan dan prosedur, mengumpulkan data 
secara induktif mulai dari tema yang khusus ke tema umum dan menafsirkan makna data. Sipapun yang terlibat dengan penelitian ini harus menerapkan cara pandang penelitian yang bergaya induktif, berfokus pada makna dan menerjemahkan kompleksitas suatu persoalan".

Penentuan dan penetapan informan dalam penelitian dengan menggunakan teknik purposive sampling, yaitu informan dipilih dengan pertimbangan dan tujuan tertentu (Sugiyono, 2005).

Dalam penelitian ini, teknik pengumpulan data yang digunakan, yaitu wawancara semi terstruktur, observasi partisipasi pasif dan dokumentasi, yaitu data yang diperoleh melalui catatan, dokumen-dokumen, arsip, foto, hasil wawancara dengan informan, laporan tahunan, monografi di Desa Karangjaya, keadaan geografis dan demografi Desa Karangjaya, struktur organisasi Perangkat Desa Karangjaya, dan sebagainya yang berkaitan objek penelitian.

Untuk menentukan keabsahan data dalam penelitian ini yang akan digunakan, yaitu derajat kepercayaan (credibility). dalam penelitian ini, peneliti menggunakan triangulasi sumber. Peneliti melakukan triangulasi dengan membandingkan data yang diperoleh melalui sumber wawancara, observasi serta dokumentasi di lapangan.

Penelitian ini dilaksanakan di Desa Karangjaya Kecamatan Namlea Kabupaten Buru dengan pertimbangan beberapa hal di antaranya Desa Karangjaya dinilai desa yang layak dijadikan sampel penelitian dengan keadaan sosial budaya yang dapat dikatakan lebih heterogen dibanding dengan desa lain di Kecamatan Namlea Kabupaten Buru, Desa Karangjaya juga memiliki kelebihan dari segi sumber daya alam serta kemudahan akses oleh peneliti juga menjadi alasan penentuan lokasi penelitian.

\section{Kinerja Pendamping Lokal Desa di Desa Karangjaya}

Penelitian ini menggunakan indikator kinerja yang dikemukakan oleh Mitchell (1978) sebagai grand teori dalam penelitian ini. Menurut Mitchell dalam Sedarmayanti (2001) untuk mengukur kinerja dapat dilakukan dengan menggunakan indikator kualitas kinerja (quality of work), ketepatan waktu (promptness), inisiatif (initiative), kemampuan (capability), dan komunikasi (communycation).

\section{- Kualitas Kerja (Quality of Work)}

Kualitas kerja dinilai dari kualitas kerja berdasarkan tugas dalam perencanaan Pembangunan dan keuangan desa, kualitas kerja dalam bidang pelaksanaan pembangunan desa, kualitas kerja dalam bidang pemberdayaan masyarakat Desa dan kualitas kerja dalam bidang pengembangan BUMDes.

Sosialisasi terhadap Undang-undang Desa No. 6 Tahun 2014 tentang Desa dan peraturan turunannya telah cukup dilaksanakan namun belum maksimal karena belum terlihat sosialisasi yang secara khusus difasilitasi oleh tenaga Pendamping Lokal Desa serta sosialisasi yang dilakukan kepada masyarakat masih belum dilakukan dengan baik. Fasilitasi terhadap musyawarah Desa untuk menyusun RPJMDes, RKPDes, serta APBDes belum terlaksana secara maksimal dikarenakan terjadinya kekosongan jabatan Kepala Desa Definitif di Desa Karangjaya sejak 2018. Rancangan Peraturan Desa tentang Kewenangan lokal berskala desa dan kewenangan berdasarkan asal-usul belum tersusun sesuai dengan target kerja Pendamping Lokal Desa dalam pelaksanaan Tugas Pendampingan.

Kualitas kerja Pendamping Lokal Desa di Desa Karangjaya dapat dilihat dari beberapa indikator output yang dianalisis sebagai berikut. 
a. Adanya Koordinasi dengan Pendamping Desa dan Pihak Terkait mengenai Pembangunan Desa

Koordinasi yang dilakukan oleh Pendamping Lokal Desa belum dilaksanakan secara maksimal karena Pendamping Lokal Desa hanya aktif berkoordinasi dengan Pendamping Desa di tingkat kecamatan dan pemerintah desa dalam hal ini perangkat desa namun koordinasi yang dilakukan bersama dengan masyarakat belum berjalan secara baik dan maksimal, padahal dalam pelaksanaan pembangunan desa keikutsertaan masyarakat desa dalam pembangunan desa menjadi hal yang sangat krusial karena masyarakat merupakan instrument pelaksana yang diharapkan peran aktif serta keikutsertaannya dalam setiap proses pelaksanaan pembangunan desa.

b. Terfasilitasinya Kerja Sama Antardesa

Belum adanya kerja sama antardesa yang berlangsung di Desa Karangjaya yang menandakan bahwa Pendamping Lokal Desa belum melaksanakan tugasnya sebagai fasilitator dengan menginisiasi atau mengedukasi pemerintah desa terkait dengan kerja sama desa.

c. Terfasilitasinya Pelaksanaan Pembangunan Desa

Dalam pelaksanaan pembangunan Desa oleh Pendamping Lokal Desa adalah Pendamping Desa harus mampu memfasilitasi pelaksanaan pembangunan desa yang sesuai dengan prinsip tata kelola yang baik.

Berdasarkan RPJMDes Karangjaya Tahun 2013-2018 terdapat sepuluh poin rencana pembangunan yang belum maksimal terlaksana sesuai dengan rencana yang telah ditetapkan. kegiatan pembangunan di Desa Karangjaya belum berjalan secara maksimal yang dapat dilihat dari masih terdapat beberapa rencana pembangunan yang belum terealisasi serta yang belum rampung sejak penetapan RPJMDes pada 2013 yang seharusnya ditargetkan rampung pada 2018 namun kenyataan di lapangan sampai pada 2020 belum maksimal dalam pencapaian target sesuai dengan yang direncanakan. Hal ini menunjukkan bahwa Pendamping Lokal Desa belum maksimal dalam pelaksanaan tugasnya untuk menjadi fasilitator terlaksananya pelaksanaan Pembangunan Desa khususnya di Desa Karangjaya. Terkait dengan indikator terfasilitasinya pelaksanaan pembangunan desa oleh Pendamping Lokal Desa di Desa Karangjaya belum maksimal sesuai dengan tugas pokok dan fungsi sebagai tenaga Pendamping Lokal Desa.

d. Terfasilitasinya ketersediaan informasi publik terkait pembangunan Desa

Dalam tugas pendampingan dalam bidang pembangunan desa oleh Pendamping Lokal Desa di Desa Karangjaya belum berjalan secara maksimal sesuai dengan harapan dan apa yang menjadi tanggung jawab serta tugas selaku Pendamping Lokal Desa serta belum mampu menjalankan fungsi fasilitasi terhadap penyampaian informasi, kemudian edukasi kepada masyarakat dan pemerintah desa terkait dengan informasi pembangunan desa serta belum mampu melaksanakan fungsi mediasi sebagai penyambung antara pemerintah desa bersama masyarakat Desa Karangjaya.

e. Kualitas Kerja dalam Bidang Pemberdayaan Masyarakat Desa

Kualitas kerja Pendamping Lokal Desa dalam pendampingan di bidang pemberdayaan belum dilaksanakan secara maksimal karena belum menyentuh elemen masyarakat secara merata serta belum terlaksananya 
beberapa kegiatan pengembangan kapasitas masyarakat Desa di Desa Karangjaya.

f. Kualitas Kerja dalam tugas Pengembangan BUMDes

Kualitas kinerja Pendamping Lokal Desa berdasarkan tugas pokok dan fungsinya mendampingi desa dalam penyelenggaraan pemerintahan desa, kerja sama desa, serta pengembangan badan usaha milik desa dan pembangunan berskala desa sebagaimana diatur dalam Peraturan Menteri Desa, Pembangunan Daerah Tertinggal dan Transmigrasi No. 18 Tahun 2019 belum maksimal.

\section{- Ketepatan Waktu (Pomptness)}

Indikator ketepatan waktu diinterpretasikan sebagai Pendamping Lokal Desa dalam melaksanakan serta menyelesaikan tugas-tugas pendampingan di Desa Karangjaya kecamatan Namlea. Indikator dari aspek ketepatan waktu menurutSiagian (1995) antara lain: penataan rencana kerja/kegiatan, ketepatan rencana kerja dengan hasil kerja, dan ketepatan waktu dalam menyelesaikan tugas.

a. Penataan Rencana Kerja/Kegiatan

Penataan perencanaan kerja di Desa Karangjaya masih belum maksimal. Hal ini disebabkan oleh belum tersusunnya RPJMDes Desa Karangjaya yang secara langsung berdampak pada kinerja pendamping lokal desa. Diakui bahwa hal tersebut bukan merupakan tanggung jawab sepenuhnya dari Pendamping Lokal Desa namun dalam melaksanakan tugas pendampingan seharusnya ada fungsi-fungsi pendampingan yang dilakukan guna mengatasi masalahmasalah yang terjadi.

b. Rencana dengan Hasil Kerja

Indikator ketepatan rencana kerja dengan hasil kerja oleh Pendamping
Lokal Desa berdasar pada pelaksanaan tugas pendampingan terhadap penyelenggaraan pemerintahan desa, kerja sama desa, pengembangan Badan usaha Milik Desa serta pembangunan berskala lokal desa belum dilakukan secara maksimal.

c. Ketepatan Waktu dalam Menyelesaikan Tugas

Penyelesaian kegiatan oleh Pendamping Lokal Desa belum sesuai dengan waktu yang telah direncanakan dan sering terjadi keterlambatan dalam penyelesaian beberapa pelaksanaan tugas sebagai pendamping lokal desa.

\section{- Inisiatif (Initiative)}

Untuk mengukur inisiatif, menurut Siagian (1995) indikator inisiatif, yaitu pemberian ide/gagasan dalam berorganisasi dan solusi terhadap permasalahan yang dihadapi.

a. Ide/Gagasan dalam Berorganisasi

Indikator ide dan gagasan dalam berorganisasi Pendamping Lokal Desa belum mampu memberikan masukanmasukan berupa ide atau gagasan selama melaksanakan tugasnya selaku Pendamping Lokal Desa di Desa Karangjaya. Namun demikian, terkait ide dan gagasan dalam pemberdayaan usaha masyarakat desa sudah cukup terlihat terutama pendampingan pengembangan produk lokal oleh kelompok usaha perempuan pada Desa Karangjaya.

b. Tindakan yang Dilakukan untuk Menyelesaikan Permasalahan

Pendamping Desa Karangjaya hanya mampu menjalankan fungsi fasilitasi dengan menjadi fasilitator terhadap koordinasi serta musyawarah di tingkat desa atau pertemuan-pertemuan lainnya sementara fungsi lainnya tidak dilaksanakan dengan baik sebagaimana 
amanat Peraturan Menteri Desa, Pembangunan Daerah Tertinggal dan Transmigrasi No. 18 Tahun 2019 yang mengatur fungsi Pendamping Lokal Desa itu terdiri dari fasilitasi, edukasi, mediasi, serta advokasi.

\section{- Kemampuan (Capability)}

Menurut Siagian (1995), indikator untuk mengukur kemampuan adalah kemampuan yang dimiliki dan kemampuan memanfaatkan sumber daya atau potensi.

Terkait kemampuan Pendamping Lokal Desa dalam bidang penyelenggaraan pemerintahan desa, kerja sama desa, pengembangan BUMDes dipengaruhi oleh minimnya pengalaman serta rendahnya tingkat pendidikan sehingga berpengaruh pada kemampuan pendamping yang belum sesuai dengan apa yang diharapkan berdasarkan ketentuan yang berlaku. Pendamping Lokal Desa belum memahami secara maksimal apa yang menjadi tugas pokok dan tanggung jawab sebagai tenaga pendamping lokal desa.

\section{- Komunikasi (Communication)}

Indikator untuk menjelaskan aspek komunikasi ini dikemukakan oleh Siagian (1995) antara lain: komunikasi intern, dan relasi dan kerja sama dengan pelaksana tugas.

Selama ini komunikasi yang dibangun oleh Pendamping Lokal Desa dengan pihak yang didampinginya belum berjalan secara maksimal karena Pendamping Lokal Desa lebih condong berkoordinasi dengan perangkat desa seperti kepala desa, sekretaris desa dan perangkatnya sementara komunikasi yang belum cukup efektif bersama dengan ketua BPD dan Direktur BUMDes yang merupakan pihak yang didampingi yang menjadi tanggung jawab atas tugas pokok dan fungsinya belum terjalin dengan baik.
Kerja sama yang terjalin antara Pendamping Lokal Desa dengan pihak yang didampingi belum terjalin secara maksimal. Kerja sama yang belum terjalin dengan maksimal ini berimbas pada pelaksanaan tugas pendampingan yang kurang maksimal.

\section{Faktor-Faktor yang Memengaruhi Kinerja Pendamping Lokal Desa di Desa Karangjaya}

Dimensi yang digunakan untuk mengidentifikasi faktor-faktor yang memengaruhi kinerja pendamping Lokal desa di Desa Karangjaya, yaitu yang dikemukakan oleh Simanjuntak (2005) antara lain: Kualitas dan Kemampuan Individu dan Sarana Pendukung.

\section{- Kualitas dan Kemampuan}

Proses rekruitmen tenaga Pendamping Lokal Desa di Maluku pada umumnya dan khususnya pendamping lokal Desa Karangjaya sudah berjalan dengan baik karena pelaksanaannya sudah sesuai dengan panduan teknis yang diatur oleh Kementerian Desa PDTT.

Pelatihan yang dilakukan kepada tenaga Pendamping Desa di Kabupaten Buru, khususnya Pendamping Lokal Desa Karangjaya belum dilaksanakan secara maksimal. Hal ini dikarenakan koordinasi yang dilakukan secara berjenjang mulai dari kementerian sampai pada tingkat Kabupaten yang memiliki tanggung jawab pembinaan belum berjalan dengan efektif dan maksimal.

\section{- Sarana Pendukung}

sarana yang diberikan kepada Pendamping Lokal Desa masih belum sepenuhnya maksimal menunjang kinerja pendamping desa karena besaran honorarium dan biaya operasional belum seimbang dengan beban kerja yang diberikan.

lingkungan kerja yang luas di mana satu orang pendamping bertugas mendampingi tiga desa sekaligus, kelengkapan struktur 
aparat pemerintahan desa, tingkat penguasaan teknologi terutama teknologi komunikasi dari masyarakat yang rendah serta rendahnya tingkat partisipasi masyarakat di Desa Karangjaya berpengaruh pada kinerja pendamping lokal desa.

\section{SIMPULAN}

1. Kinerja Pendamping Lokal Desa di Desa Karangjaya belum maksimal sesuai dengan tugas pokok dan fungsinya sebagaimana diatur dalam Peraturan Menteri Desa, Pembangunan Daerah Tertinggal dan Transmigrasi No. 18 Tahun 2019 tentang Pedoman Umum Pendampingan Masyarakat Desa.

2. Kinerja pendamping lokal Desa Karangjaya yang masih belum maksimal dipengaruhi oleh beberapa faktor di antaranya belum maksimalnya kegiatan pengembangan kapasitas serta sarana pendukung dalam pelaksanaan tugas pendampingan yang masih minim.

\section{SARAN}

1. Pendamping Lokal desa agar lebih memahami tugas pokok dan fungsinya sesuai dengan ketentuan yang berlaku

2. Kementerian Desa, Pembangunan Daerah tertinggal dan Transmigrasi, Pemerintah Daerah baik di tingkat Provinsi maupun Pemerintah Kabupaten/Kota agar menerapkan sistem reward dan punishment terhadap kinerja Pendamping Lokal desa.

3. Pendamping Lokal desa agar mampu mendorong dan memaksimalkan terselenggaranya program Inovasi Desa

4. Pendamping Lokal Desa agar lebih meningkatkan komunikasi aktif bersama dengan pemerintah Desa Karangjaya, BUMDes, Badan Permusyawaratan Masyarakat Desa dan masyarakat pada umumnya.
5. Pemerintah Daerah Kabupaten Buru sesuai tugas dan fungsinya agar memaksimalkan kegiatan peningkatan kapasitas Pendamping Lokal Desa melalui Pendidikan dan pelatihan, bimbingan teknis dan kegiatan lainnya guna meningkatkan kemampuan teknis serta kemampuan komunikasi.

6. Kementerian Desa Pembangunan Daerah Tertinggal dan Transmigrasi serta Pemerintah Daerah Provinsi Maluku melalui Satker P3MD agar melakukan evaluasi terkait honorarium Pendamping Lokal Desa berdasarkan beban tugas dan kondisi geografis serta peningkatan prasarana dan sarana dalam rangka peningkatan tugas dan fungsi Pendamping Lokal Desa.

7. Kementerian Desa Pembangunan Daerah Tertinggal dan Transmigrasi agar melakukan evaluasi terhadap kebijakan dengan melibatkan Pemerintah Daerah Kabupaten/Kota yang lebih memahami karakteristik Desa.

\section{DAFTAR RUJUKAN}

Adisasmita, Raharjo. 2006. Membangun Desa Partisipatif. Graha Ilmu: Yogyakarta.

2006. Pembangunan Perdesaan dan Perkotaan. Graha Ilmu:

Yogyakarta.

2013. Pembangunan Perdesaan; Pendekatan Partisipatif, Tipologi,Strategi, Konsep Desa Pusat Pertumbuhan. Graha Ilmu: Yogyakarta.

Arikunto, S. 2010. Prosedur Penelitian Suatu Pendekatan Praktik. Jakarta: Rineka Cipta.

Creswell, John, W., 2016, Resrarch Design, Pustaka Pelajar, Yogyakarta.

Inu Kencana Syafiie. 2009. Pengantar Ilmu Pemerintahan. Cetakan Kelima. Bandung: Refika Aditama

Mahsun, Mohamad, 2006. Pengukuran Kinerja Sektor Publik. Yogyakarta: BPFE 
Moleong, Lexy J. 2013. Metode Penelitian Kualitatif. Edisi Revisi. Bandung: PT Remaja Rosdakarya.

Nazir. 1988. Metode Penelitian. Jakarta: Ghalia Indonesia.

Ndraha, Taliziduhu. 2011. Kybernologi Sebuah Rekonstruksi Ilmu Pemerintahan. Jakarta: Rineka Cipta

Paslong, Harbani, 2013,Metode Penelitian Administrasi Publik, Alfabeta, Bandung

Prawirosentono, Suryadi. 1999. Manajemen Sumber Daya Manusia: Kebijakan Kinerja Karyawan, Kiat Menuju Organisasi Kompetitif dalam Perdagangan Bebas Dunia. BPFE: Yogyakarta.

Prawirosentono, Suryadi. 1999. Manajemen Sumber Daya Manusia: Kebijakan Kinerja Karyawan, Kiat Menuju Organisasi Kompetitif Dalam

Purwanto. 2010. Metode Penelitian Kuantitatif. Bandung: Remaja Rosda Karya.

Robbins, Stephen P. 2000. Essentials of organizational behavior. Printice Hall International Inc: New Jersey.

Sastrohadiwiryo, B siswanto, 2003, Manajemen Tenaga Kerja Indonesia, Jakarta: Bumi Aksara

Sedarmayanti. 2007. Manajemen Sumber Daya Manusia, Reformasi Birokrasi,dan Manajemen Pegawai Negeri Sipil. Bandung: Refika Aditama.

Simanjuntak, Payaman J. 2005. Manajemen dan Evaluasi Kinerja. Jakarta: FE UI.

Simangungsong, fernandes, 2016, Metodologi Penelitian Pemerintahan, Alfabeta, Bandung

Sinambela, Poltak. Lijan. 2012. Kinerja Pegawai Teori Pengukuran dan Implikasi. Yogyakarta: Graha Ilmu.

Suharto, Edi, 2016, Membangun Masyarakat Memberdayakan rakyat, Bandung: 9Refika Aditama

Sugiyono. 2005. Metode Penelitian Bisnis. Bandung: Alfabeta

Sugiyono, 2013, Metode Penelitian Kuantitatif, Kualitatif dan $R \& D$, Alfabeta, Bandung
Suharsaputra, Uhar, 2012, Metode Penelitian,Kuantitatif, Kualitatif dan $R$ \& $D$, Alfabeta, Bandung

Sudarmanto. 2009. Kinerja dan Pengembangan Kompetensi SDM. Yogyakarta: Pustaka Pelajar

Suharto, Edi, 2016. Membangun Masyarakat Memberdayakan Masyarakat, Bandung: PT Refika Aditama

Steers, R.M. and Porter, L. W. 2003. Motivation and Work Behavior. New York: Mc GrawHill Book Company

Wasistiono, Sadu dan Simangungsung, Fernandes, 2015 Metodologi Ilmu Pemerintahan (Edisi Revisi yang Diperluas), IPDN Press, Jatinangor

Wasistiono, Sadu dan Tahir, Irwan, 2006, Prospek Pengembangan Desa, Bandung: CV. Fokus Media

Winardi, J, 2004, Manajemen Perilaku Organisasi, Prenada Media, Jakarta

Wiryasaputra, Totok S. 2006, Pendampingan dan Konseling Psikologi, Yogyakarta: Galangpress

\section{Peraturan Perundang-Undangan:}

Undang-Undang Dasar Tahun 1945

Undang-Undang No. 6 Tahun 2014 tentang Desa.

Peraturan Pemerintah No. 43 Tahun 2014 tentang Peraturan Pelaksanaan Undang-Undang No. 6 Tagun 2014 tentang Desa

Peraturan Pemerintah No. 47 Tahun 2015 tentang Perubahan atas Peraturan Pemerintah No. 43 Tahun 2014 tentang Peraturan Pelaksanaan Undang-Undang No. 6 Tagun 2014 tentang Desa

Peraturan Menteri Desa, Pembangunan Daerah Tertinggal dan Transmigrasi No. 18 Tahun 2019 tentang Pedoman Umum Pendampingan Masyarakat Desa.

\section{Sumber Lain:}

https: //idm.kemendesa.go.id

https: //bps.go.id

https: //maluku.bps.go.id

https: //mimbarrakyat.com

https: //kompas.com

https: //wartamaluku.com 